\title{
Anatomic Description of the Ulna of the White-Footed Tamarin (Saguinus leucopus Günther, 1876)
}

\author{
Descripción Anatómica de la Ulna del Tití Gris (Saguinus leucopus Günther, 1876)
}

\author{
Juan Fernando Vélez-García*; Jorge Eduardo Duque-Parra*,***** \& John Barco-Ríos ${ }^{* * *}$
}

VÉLEZ-GARCÍA, J. F.; DUQUE-PARRA, J. E. \& BARCO-RÍOS, J. Anatomic description of the ulna of the White-footed tamarin (Saguinus leucopus Günther, 1876). Int. J. Morphol., 34(4):1392-1395, 2016.

SUMMARY: This document is a description of the macroscopic functional anatomy of the ulna bony prominences in the Whitefooted Tamarin (Saguinus leucopus), a neotropical endemic, and monotypic primate of Colombia. Few studies have been conducted on its anatomy, and thus its ulnar morphology, an essential element for this animal's quadrupedal arboreal locomotion, remains unknown. This study is based on eight specimens, fixed in formalin at $10 \%$ whose ulnas were extracted in order to describe the main bony prominences along with muscular and ligamentous fixation functions. These elements of the locomotor apparatus and the multiple anatomical contours of the ulna of the White-footed Tamarin, exhibit characteristics for positional and articular adjustment with other bones of the forelimb in harmony with the attachments of the muscles, essential for quadrupedal arboreal locomotion.

KEY WORDS: Anatomy; Attachments; Osteology; Primate.

\section{INTRODUCTION}

The White-footed Tamarin (Saguinus leucopus) is a neotropic, endemic and monotypic primate of Colombia (Defler, 2010), it is included by the IUCN (International Union for Conservation of Nature and Natural Resources) on the list of endangered species (Morales-Jiménez et al., 2008). It is also listed by CITES (Convention on International Trade in Endangered Species of Wild Fauna and Flora, 2012) in Appendix I. This is an exclusive New World genus of small size, without opposable thumbs; it has claws on all the digits of the hand and also morphological adaptations for quadrupedal locomotion in trunks and branches of trees to find its food (Defler; Morales-Jiménez et al.) and to fulfill its ecological niche. There are few scientific studies on the anatomy of the Saguinus leucopus (Stevenson et al., 2010), although recently the elements of the gross anatomy of the radius and humerus in relation to the function of their bone prominences for muscles and ligaments fixation and for articulation with adjacent bones (Duque-Parra et al., 2014; Duque-Parra \& Vélez-García, 2014) like the ulna have been described.

The bones and joints are arranged as levers, hence, they can be moved by the muscles, which also allow the animal to remain standing (Kardong, 2012). Thus, the muscles have to be attached in the bones as they do in the ulna, which provides attachments to muscles that allow different movements at the elbow, carpus and digits (Standring, 2008; Dyce et al., 2012; Moore et al., 2013). The ulna also has a caudal position in the forearm of quadruped mammals and is merged with the radius like in equine and bovine. It also forms trochoids diartrosis with the radius in canine and feline that allows supination and pronation (Dyce et al.), which is an important characteristic in primates, since it must allow different positions of the hands to move in the branches of trees or to allow manipulation in humans (Ankel-Simons, 2007).

Thoracic limbs are the most affected by trauma in chimpanzees, bonobos, and gorillas (Jurmain, 1997). There have even been some frequent abnormalities in the muscleskeletal system of the Saguinus leucopus (Varela et al., 2010) and the ulna may be involved. Therefore, this study describes the functional anatomy of the ulna of this specie in order to have a basis for clinical and surgical procedures that involve the ulna and its relations. This aim may be extended to comparative anatomy studies that would be useful

\footnotetext{
* Departamento de Sanidad Animal, Facultad de Medicina Veterinaria y Zootecnia, Universidad del Tolima, Ibagué, Colombia.

** Departamento de Ciencias Básicas para la Salud, Universidad de Caldas en convenio con CORPOCALDAS, Manizales, Colombia.

**** Departamento de Ciencias Básicas Biológicas, Universidad Autónoma de Manizales, Manizales, Colombia.
} 
to contrast based on recent findings on the analysis of the distal ulna of the Australopithecus afarensis and Australopithecus africanus. This might give better clues about the functional role of the joint with the carpus in hominids (Tallman, 2015).

\section{MATERIAL AND METHOD}

Eight White-footed Tamarin (Saguinus leucopus) specimens were studied, four females and four males with weights between 300 and 460 grams, they died of natural causes between 2012 and the first quarter of 2013 in the centers of attention and appreciation of wildlife CORPOCALDAS (Colombia). They did not have a clinical history of musculoskeletal disease. They were fixed by subcutaneous intramuscular infiltrations and in cavities with a solution of $10 \%$ formalin, 5 $\%$ mineral oil and $1 \%$ phenic acid. Subsequently, they were immersed in the same solution but without mineral oil for a minimum period of 48 hours. The forearms were dissected from the superficial plane to the deep plane; photographic records of the proceedings were taken, the anatomy and relations for the function of the ulna were emphasized. Since the Saguinus leucopus is a quadruped animal (Defler), the anatomical findings were described in terms indicating direction and situation when the limbs are supported (Termini ad membra spectantes) and using the systematic terminology of the Nomina Anatomica Veterinaria (ICVGAN, 2012).

\section{RESULTS}

The ulna (Ulna) of the Saguinus leucopus is a long bone. During pronation, since this monkey is a quadruped animal, it has a proximal epiphysis in a caudomedial position, while its diaphysis and distal epiphysis are in caudolateral position with respect to the radius. Its proximal epiphysis projects into proximal surpassing the radius head, forming a highly developed olecranon with a wide tuberosity (Tuber olecrani) for the insertion of the triceps brachii muscle (Fig.1); a medial surface for the insertion of the anconeusepitrochlearis muscle, and a lateral surface for the muscle mass homologous to the anconeous. A pointed process unfolds in the caudomedial margin of the olecranon for the insertion of the dorsi-epitrochlearis muscle. The trochlear notch (Incisura trochlearis) is in a cranial direction to the olecranon to join the humerus, which at its proximal end forms an anconeus process (Processus anconeus) that delves into the olecranon fossa of the humerus when the elbow is in full extension (Fig. 1). In the distal end of the trochlear notch is a prominent medial coronoid process (Processus coronoideus medialis), and lateral to it, is the radial notch and a noticeable lateral projection corresponding to the lateral coronoid process (Processus coronoideus lateralis) (Fig. 1). The annular ligament that surrounds the radial head is fixed to the two coronoid processes, and at a short distance from the medial coronoid process to distal is a tuberosity for the insertion of the brachialis muscle (Fig. 1).
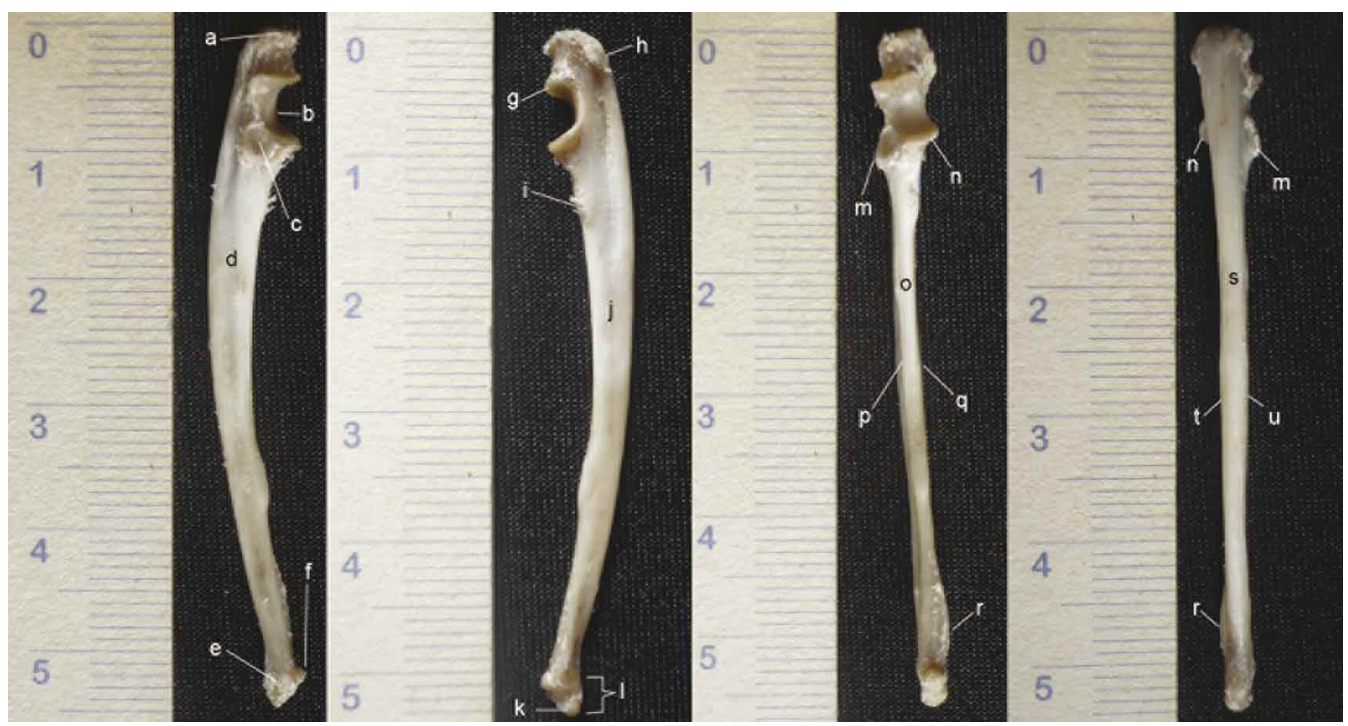

Fig. 1. Right ulna of a specimen of Saguinus leucopus with different views: Lateral, Medial, Cranial and Caudal from left to right. (a) Olecranon tuberosity, (b) Trochlear notch, (c) Radial notch, (d) Lateral surface, (e) Groove for the tendon of the extensor carpi ulnaris muscle, (f) Parastyloid process, (g) Anconeous process, (h) Process for the insertion of the dorsi-epitrochlearis muscle, (i) Ulnar tuberosity, (j) Medial surface, (k) Styloid process, (l) Ulnar head, (m) Lateral coronoid process, (n) Medial coronoid process, (o) Cranial surface, (p) Interosseous margin (craniolateral), (q) Craniomedial margin, (r) Crest for the insertion of the pronator quadratus, (s) subcutaneous surface (caudal), (t) Caudomedial margin, (u) Caudolateral margin. 
Along the ulna, four surfaces (Facies) are formed: a slightly curved caudal surface, free from attachments and observed once the skin is removed; a lateral surface that forms a groove along its length for the origin of the abductor digit I (Pollicis) longus muscle and the deep extensor muscles of the digits; a medial concave surface at its proximal third and flattened at its two distal thirds; and a cranial surface on the three proximal quarters. There are four margins (Margo) limiting these sides: a caudolateral and a caudomedial found on the sides of the caudal margin. The antebrachial fascia, deep extensor muscles and ulnar head of the flexor carpi ulnaris are respectively attached to this caudal site. There are two margins to cranial, where the interosseous is formed from the radial notch laterally, and is providing fixation to the interosseous membrane, and a blunt one towards medial distal to the ulnar tuberosity. In the fourth distal of the ulna, it is obliquely directed in distolateral side forming a more acute ridge that reaches the ulnar head and provides insertion to the pronator quadratus. The cranial and medial surfaces, and the cranial margin give rise to the ulnar heads of the deep digital flexor muscles. At the distal end of the ulna, there are a head and a styloid process with an articular surface (Facies articularis carpea) for the carpoulnar bone (Os carpi ulnare). In the proximal part of the styloid process to cranial a parastyloid process is projected, the articular disc for the carpus is attached to it and it fixes with the radius. On its lateral surface, a groove directed obliquely towards caudodistal to the distal tendon of the extensor carpi ulnaris muscle is observed.

\section{DISCUSSION}

In quadrupedal locomotion primates like Galago senegalensis the lateral surface of the ulna has a groove in the proximal two-thirds (Stevens et al., 1977), differing from Saguinus leucopus that has this groove throughout the ulna for the origin of the deep extensor muscles. This is similar to the findings in Galago and Lemur, except that for these species, it is described as a more marked fosse (Mivart, 1867). In Ateles sp. and other primates of the family Cebidae, there is a concave medial surface (Mivart), like in Galago senegalensis (Stevens et al.), but in the latter it is present in the proximal third, which is similar to our finding in Saguinus leucopus, which is an important feature for the fixation of some carpal and digits flexors muscles required for locomotion in branches and tree trunks, as shown in the ulnas of Alouatta seniculus, Ateles paniscus and Cebus spp. (Youlatus, 2000).

The crest for insertion of the pronator quadratus muscle is highly variable among primates (Mivart), and is absent in humans (Standring; Moore et al.). It has a rudimentary form or sometimes it is highly marked as in the Lemur (Mivart) and our findings in Saguinus leucopus, which must have been formed by the constant pressure of the pronator quadratus on the ulna for a quadrupedal locomotion to be performed, as it requires a longer pronation of the forearm and hand.

Since the supinator muscle does not have ulnar origin, the ulna of Saguinus leucopus does not form a supinator crest as it does in humans (Standring; Moore et al.) and as it should happen in nonhuman primates whose ulnar origin lies in the supinator muscle (Cribillero et al., 2009; Michilsens et al., 2009; Aversi-Ferreira et al., 2010; Diogo et al., 2012; Diogo \& Wood, 2012).

The olecranon tuberosity, the anconeous process and both coronoid processes are described in the ulna of domestic mammals (Dyce et al.) and the terms are found in the terminology of the Nomina Anatomica Veterinaria (ICVGAN) but not in the Terminologia Anatomica for the human (FICAT, 1998), which is the basis primate for comparisons. Therefore, they are not described in other primates (Mivart; Ackermann, 2003), but due to the morphology that these prominences exhibited in the ulna of Saguinus leucopus, they deserve reference, showing that this species has acquired morphological characteristics in the ulna for quadrupedal locomotion. The medial coronoid process is the counterpart to the coronoid process in humans, and although the human ulna has laterally a short process to the radial notch (Standring; Moore $e t$ al.), it is not described as a process.

In conclusion, the ulna of Saguinus leucopus has been adapted forming wide bone prominences, such as four margins and four surfaces that are the source for the fleshy attachments of muscles involved in carpus and digits movements, apart from an extensive development of the olecranon and a tuberosity for the fixation of extensor muscles and elbow flexors such as the triceps brachii and brachialis respectively. It also has cartilaginous regions for diartrosis with the humerus, radius and carpus such as the trochlear notch, the coronoid process, the radial notch and the styloid process, which should allow the necessary movements for their locomotion. Thus, ultimately the prominences for muscle and joint fixations represent efficient adaptations that have occurred in the Saguinus leucopus for its quadrupedal locomotion in trees trunks and branches, and the knowledge of the ulna should be considered for clinical and surgical procedures in this specie.

VÉLEZ-GARCÍA, J. F.; DUQUE-PARRA, J. E. \& BARCO-RÍOS, J. Descripción anatómica de la ulna del tití gris (Saguinus leucopus Günther, 1876). Int. J. Morphol., 34(4):1392-1395, 2016. 
RESUMEN: El presente trabajo es una descripción de la anatomía macroscópica y funcional de los relieves óseos de la ulna del tití gris (Saguinus leucopus), un primate neotropical, endémico y monotípico de Colombia, con escasos estudios sobre su anatomía, y por ende de la morfología ulnar, elemento fundamental para la locomoción cuadrúpeda de este animal arbóreo que permanece desconocida. Para ello, se tomaron como base del estudio ocho especímenes fijados con formalina al $10 \%$ y de ellos se extrajeron sus ulnas, describiendo los principales relieves óseos con sus funciones de fijación muscular y ligamentosa. Estos elementos del aparato locomotor con sus múltiples relieves anatómicos de la ulna del tití gris, presentan características para la adaptación posicional y articular con otros huesos del miembro torácico de manera armónica para la fijación de músculos indispensables en su locomoción cuadrúpeda arbórea.

\section{PALABRAS CLAVE: Anatomía; Inserciones; Osteología;} Primate.

\section{REFERENCES}

Ackermann, R. R. A Comparative Primate Anatomy Dissection Manual. Cape Town, University of Cape Town, 2003.

Ankel-Simons, F. Primate Anatomy: An Introduction. 3rd ed. Oxford, Academic Press, 2007.

Aversi-Ferreira, T. A.; Diogo, R.; Potau, J. M.; Bello, G.; Pastor, J. F. \& Aziz, M. A. Comparative anatomical study of the forearm extensor muscles of Cebus libidinosus (Rylands et al., 2000; Primates, Cebidae), modern humans, and other primates, with comments on primate evolution, phylogeny, and manipulatory behavior. Anat. Rec. (Hoboken), 293(12):2056-70, 2010.

Cribillero Ch. N.; Sato S. A. \& Navarrete Z. M. Anatomía macroscópica de la musculatura del miembro anterior del mono machín blanco (Cebus albifrons). Rev. Investig. Vet. Perú, 20(2):143-53, 2009.

Defler, T. R. Historia Natural de los Primates Colombianos. $2^{\mathrm{a}}$ ed. Bogotá, Universidad Nacional de Colombia, 2010.

Diogo, R.; Richmond, B. G. \& Wood, B. Evolution and homologies of primate and modern human hand and forearm muscles, with notes on thumb movements and tool use. J. Hum. Evol., 63(1):64-78, 2012.

Diogo, R. \& Wood, B. A. Comparative Anatomy and Phylogeny of Primate Muscles and Human Evolution. Boca Raton, CRC Press, 2012.

Duque-Parra, J. E. \& Vélez-García, J. F. Anatomical and functional description of humerus in the white-footed tamarin (Saguinus leucopus). Int. J. Morphol., 32(1):147-50, 2014.

Duque-Parra, J. E.; Vélez-García, J. F. \& Barco Ríos, J. Anatomical and functional description of the radius of white-footed tamarin (Saguinus leucopus). Int. J. Morphol., 32(3):914-17, 2014.

Dyce, K. M.; Sack, W. O. \& Wensing, C. J. G. Anatomía Veterinaria. 4th ed. Ciudad de México, El Manual Moderno, 2012.

Convention on International Trade in Endangered Species of Wild Fauna and Flora (CITES). Appendices I, II and III. 2012. Available from: http://www.cites.org/esp/app/appendices.php
Federative International Committee on Anatomical Terminology (FICAT). Terminologia Anatomica. International Anatomical Terminology. New York, Thieme Medical Publishers, 1998.

International Committee on Veterinary Gross Anatomical Nomenclature (ICVGAN). Nomina Anatomica Veterinaria. 5th ed. rev. Hannover, World Association of Veterinary Anatomists, 2012.

Kardong, K. Vertebrates: Comparative Anatomy, Function, Evolution. 6th ed. New York, Mc Graw Hill, 2012.

Jurmain, R. Skeletal evidence of trauma in African apes, with special reference to the gombe chimpanzees. Primates, 38(1):1-14, 1997.

Michilsens, F.; Vereecke, E. E.; D'août, K. \& Aerts, P. Functional anatomy of the gibbon forelimb: adaptations to a brachiating lifestyle. J. Anat., 215(3):335-54, 2009.

Mivart, G. On the appendicular skeleton of the primates. Philos. Trans. R. Soc. Lond., 157:299-429, 1867.

Moore, K. L., Dalley, A. F., \& Agur, A. M. R. Clinically Oriented Anatomy. Philadelphia, Wolters Kluwer Health/Lippincott Williams \& Wilkins, 2013.

Morales-Jiménez, A. L.; Link, A. \& Stevenson, P. Saguinus leucopus. The IUCN Red List of Threatened Species, e.T19819A9019454, 2008. Available from: http://www.iucnredlist.org/details/19819/0

Standring, S. Gray's Anatomy: The Anatomical Basis of Clinical Practice. 40th ed. Edinburgh, Churchill Livingstone/Elsevier, 2008.

Stevens, J. L.; Meyer, D. M. \& Edgerton, V. R. Gross anatomy of the forelimb and shoulder girdle of the Galago senegalensis. Primates, 18(2):435-52, 1977.

Stevenson, P. R.; Guzman, D. C. \& Defler, T. R. Conservation of Colombian primates: An analysis of published research. Trop. Conserv. Sci., 3(1):45-62, 2010.

Tallman, M. Phenetic and functional analyses of the distal ulna of Australopithecus afarensis and Australopithecus africanus. Anat. Rec. (Hoboken), 298(1):195-211, 2015

Varela, N.; Brieva, C. \& Galindo, C. Causas de Mortalidad y Morbilidad de los Primates de la Unidad de Rescate y Rehabilitación de Animales Silvestres (URRAS) entre 1996 y 2003. In: Pereira-Bengoa, V.; Stevenson, P. R.; Well, M. L. \& Nassar-Montoya, F. Primatology in Colombia: Advances to Top Goals. Bogotá, Fundación Universitaria San Martín, 2010. pp.171-89.

Youlatus, D. Functional anatomy of forelimb muscles in Guianan Atelines (Platyrrhini: Primates). Ann. Sci. Nat., 21(4):137-51, 2000.

\section{Correspondence to: \\ Juan Fernando Vélez García \\ Departamento de Sanidad Animal \\ Facultad de Medicina Veterinaria y Zootecnia \\ Universidad del Tolima \\ Barrio Santa Helena \\ Ibagué - COLOMBIA}

Email: jfvelezg@ut.edu.co

Received: 17-10-2015

Accepted: 10-08-2016 